\title{
Pengembangan E-Modul Trigonometri (EMOTIGON) Berbasis Android untuk Siswa SMA Kelas X
}

\author{
Avhiyana Ariestazya Sari ${ }^{1}$, Novisita Ratu ${ }^{2}$ \\ 1,2 Program Studi Pendidikan Matematika, Fakultas Keguruan Ilmu Pendidikan, Universitas Kristen Satya Wacana, \\ J1, Diponegoro 52-60, Salatiga \\ 202017031@student.uksw.edu
}

\begin{abstract}
Most students were accustomed to memorizing the formula of trigonometry, which makes it difficult for students to understand the material of trigonometry. Trigonometry E-Modul research (EMOTIGON) has the aim of making valid, practical, and effective Android based media so that can be used for high school students to understand the material of trigonometry. The resulting media is an application that can be accessed offline. The type of Research and Development (R\&D) with the ADDIE model which has 5 stages, namely analyze, design, develop, implement, and evaluate. The trigonometry E-Module learning media has passed a series of tests, namely: (1) validation test material aspect obtained an average of 4.2 in valid category, (2) the display validation test of 4.4, in display category, and (3) practicality test obtained an average value of 4.5, practical category. EMOTIGON was tested on a limited basis as many as 15 students with an average pretest of $34.67 \mathrm{and}$ an average posttest of 66, which indicates that there is an effect of media usage towards the improvement of students' average test results. This study also receives positive responses from students regarding the use of the media.
\end{abstract}

Keywords: Development, E-Module, Trigonometry, Android, Senior High School

\begin{abstract}
Abstrak
Sebagian besar siswa terbiasa dengan menghafalkan rumus trigonometri, sehingga siswa kesulitan jika memahami materi trigonometri. Penelitian E-Modul trigonometri (EMOTIGON) memiliki tujuan untuk membuat media berbasis Android yang valid, praktis dan efektif sehingga dapat digunakan siswa Sekolah Menengah Atas untuk memahami trigonometri. Media yang dihasilkan berupa aplikasi yang dapat diakses secara offline. Jenis penelitian yang digunakan yakni Research and Dvelopment (R\&D) dengan model ADDIE yang memiliki 5 tahap yaitu analyze, design, develop, implement dan evaluate. Media pembelajaran E-Modul trigonometri telah melalui serangkaian pengujian, yaitu: (1) uji validasi dari aspek materi diperoleh rata-rata 4,2 masuk kategori valid, (2) uji validasi aspek tampilan sebesar 4,4, pada kategori valid dan (3) uji kepraktisan diperoleh nilai rata-rata 4,5, kategori praktis. EMOTIGON diujicobakan secara terbatas sebanyak 15 siswa dengan rata-rata pretest 34,67 dan posttest rata-ratanya 66 , menandakan adanya pengaruh penggunaan EMOTIGON dengan meningkatnya rata-rata tes pada siswa. Diperoleh juga respon yang positif dari siswa terhadap penggunaan media.
\end{abstract}

Kata kunci: Pengembangan, E-Modul, Trigonometri, Android, SMA

Copyright (c) 2022 Avhiyana Ariestazya Sari

$\triangle$ Corresponding author: Avhiyana Ariestazya Sari

Email Address: $202017031 @$ student.uksw.edu (Jl. Diponegoro 52-60 Salatiga)

Received 21 November 2021, Accepted 02 February 2022, Published 02 February 2022

\section{PENDAHULUAN}

Belajar matematika sangatlah penting bagi siswa karena hampir setiap mata pelajaran membutuhkan matematika. Menurut Rachmayani (2014), matematika merupakan ratu sekaligus pelayan artinya matematika menjadi sumber dari semua ilmu pengetahuan serta meladeni kebutuhan ilmu pada hal yang dikembangkan dan operasionalnya. Sehingga matematika dapat dikatakan sebagai dasar dari segala ilmu yang penting peranannya dalam pengetahuan serta teknologi. Salah satu materi matematika yang melekat kaitannya pada pengetahuan dan teknologi yaitu trigonometri.

Trigonometri yakni salah satu materi dalam matematika yang diujikan pada Ujian Nasional, karena hal tersebut trigonometri tergolong materi yang sulit untuk dipahami siswa dalam 
pembelajaran di kelas sehingga sebagian besar siswa merasa kurang menyukai materi trigonometri (Abdullah \& Yunianta, 2018). Menurut Putu, dkk (2019) trigonometri digunakan pada materi-materi selanjutnya dalam matematika untuk menyelesaikan permasalahan di berbagai bidang lain. Akibatnya, kurangnya motivasi untuk belajar matematika. Berdasarkan data dari Pamer UN SMA pada tahun 2019, persentase siswa yang menjawab benar dalam materi aljabar sebesar 38,50\%, materi statistika $36,63 \%$, serta pada materi geometri dan trigonometri hanya berkisar sebersar 36,54\%. Pada materi trigonometri sendiri hanya sebesar $24,97 \%$ saja, maka dapat dikatakan bahwa kurangnya pemahaman siswa pada materi trigonometri sehingga persentase jawaban benar siswa pada materi trigonometri, masih tergolong sangat rendah. apalagi pembelajaran trigonometri biasanya, masih menggunakan papan tulis sebagai media yang digunakan untuk menjelaskan konsep trigonometri yang sulit. Oleh karena itu, dengan kurangnya pemahaman siswa dan rendahnya persentase UN siswa serta kurangnya media yang mendukung, maka diperlukan adanya media pembelajaran untuk dapat membantu pemahaman materi trigonometri pada siswa (Ekawati, 2016).

Pelaksanaan kegiatan pembelajaran dengan berkembangnya teknologi yang tidak ada batasan waktu dapat mempermudah siswa dan juga guru (Sadikin \& Hakim, 2019). Selain itu menurut Setyono dkk (2017) pengembangan media pembelajaran sangat penting mulai dari sekarang, selama memuat tujuan untuk memantapkan pemahaman konsep siswa. Media pembelajaran dapat berupa media yang konkret berupa alat peraga, dapat juga berupa media yang berbasis IT (Information Technologi) atau yang sering kita sebut dengan Teknologi Informasi. Adanya teknologi terkini, kegiatan belajar mengajar akan berkembang lebih efisien dan efektif karena dapat dengan mudah diakses dalam mendapatkan informasi (Sarwiko, 2012). Pemanfaatan teknologi, dapat dikembangkannya media yaitu E-Modul. E-Modul (modul elektronik) merupakan teknologi, perangkat yang terdapat informasi dan sebagai alat komunikasi yang memudahkan belajar dengan adanya tampilan gambar, audio, video, dan animasi. Penggunaan media elektronik dalam kegiatan pembelajaran dapat dipermudah, maka kualitas suatu pembelajaran dapat meningkat. Penggunaan $E$ Modul di dalam pelajaran matematika sangat cocok agar pemahaman materi trigonometri pada siswa dapat ditingkatkan ketika pembelajaran. Hal tersebut dikarenakan E-Modul memiliki kelebihan dalam perancangannya, yang mana siswa dapat menggunakannya secara mandiri dan dengan adanya desain yang dapat membuat siswa tertarik sehingga timbul motivasi siswa untuk belajar. (Sudawan dkk, 2017).

E-Modul dapat digunakan untuk mengatasi permasalahan siswa dalam pemahaman konsep pada materi matematika. Salah satu materi yang dapat divisualisasikan melalui E-Modul yaitu trigonometri. Pada trigonometri terdapat gambar dan grafik yang sulit dipahami jika hanya terbatas pada gambar yang tercetak di buku. Sehingga E-Modul dapat digunakan sebagai solusi untuk memecahkan masalah siswa yang merasa kesulitan memahami materi trigonometri. Materi trigonometri yang sulit dapat didesain menjadi lebih menarik dengan menggunakan animasi dalam E-Modul. Seperti yang dikatakan Ula \& Fadila $(2018,202)$ belajar trigonometri yang nyaman dan dapat membuat siswa 
senang, dikarenakan media yang siswa gunakan lebih menarik perhatian dan motivasi belajar siswa. Menggunakan E-Modul dapat lebih interaktif daripada menggunakan modul cetak dan lebih fleksibel digunakan dimanapun, kapanpun secara individu atau kelompok (Suarsana \& Mahayukti, 2013). Meskipun E-Modul memiliki banyak kelebihan, E-Modul dapat diakses dengan menggunakan perangkat yang mana tidak semua siswa memiliki sebuah perangkat untuk mengakses E-Modul (Putri, 2019).

Pembelajaran menggunakan E-Modul biasanya menggunakan komputer. Selain komputer, EModul dapat diterapkan dengan menggunakan perangkat lain seperti smartphone. Dengan menggunakan smartphone siswa lebih memahami materi yang diberikan dan lebih menarik karena manyajikan animasi pada E-Modul yang berbasis Android. Menurut Majid (2020), Android berisikan sistem operasi, aplikasi dan middlewaere berbasis linux pada perangkat mobile. Jadi untuk pembelajaran yang sulit salah satunya materi trigonometri menggunakan animasi menjadi lebih mudah karena dalam memahami konsep matematika yang abstrak dapat menjadi jelas. E-Modul berbasis Android juga dapat mempermudah siswa dalam belajar karena sekarang ini banyak siswa yang memiliki smartphone Android.

Penelitian pengembangan yang membuktikan E-Modul efektif digunakan dalam pembelajaran yaitu Muhammad \& Roisatun (2019) yang berjudul "Pengembangan E-Modul Kalkulus Berbasis Geogebra dengan Dukungan Website Moodle", Permatasari dkk (2017) yang berjudul "Pengembangan E-Modul Berbasis Adobe Flash Pada Pokok Bahasan Sistem Reproduksi untuk Kelas IX MIPA SMA", dan Herawati \& Muhtadi (2018) yang berjudul "Pengembangan Modul Elektronik (E-Modul) Interaktif Pada Mata Pelajaran Kimia Kelas XI SMA". Berdasarkan beberapa hasil penelitian tersebut, maka sebagai pertimbangan terhadap permasalahan yang ada pada siswa, peneliti memutuskan melakukan pengembangan media pembelajaran dalam bentuk E-Modul yang berbasis Android.

E-Modul yang akan dikembangkan berisi tentang materi trigonometri, yang diberi nama EMOTIGON (E-Modul Trigonometri). Media E-Modul dikembangkan dengan menggunakan model pengembangan ADDIE untuk digunakan secara individu atau mandiri dalam kelas juga dapat diluar kelas. Modul elektronik ini diberikan animasi yang dapat mempermudah pemahaman siswa dalam belajar materi trigonometri, tetapi juga diberikan latihan soal yang dapat membantu siswa dalam berlatih soal trigonometri. Tampilan pada E-Modul tersebut didesain dengan gambar karakter, soal latihan, pembahasan soal dan juga lebih colorfull dengan sedikit sentuhan corak batik pada background. Animasi yang ditampilkan, dapat berupa tombol-tombol yang dapat ditekan yang nantinya dapat mempermudah siswa dalam belajar, gambar dan tulisan yang bergerak, sehingga siswa menjadi termotivasi untuk belajar dan semakin paham dengan materi yang diajarkan.

Berdasarkan deskripsi di atas, peneliti mengembangkan E-Modul trigonometri (EMOTIGON) berbasis Android berupa aplikasi yang dapat diakses secara offline tanpa menggunakan koneksi internet. Peneliti berharap media yang dikembangkan dapat membantu pemahaman siswa terhadap 
trigonometri khusunya pada subbab perbandingan trigonometri sudut berelasi. Penelitian ini memiliki tujuan untuk memperoleh hasil apakah valid, praktis dan efektif dari E-Modul trigonometri (EMOTIGON) berbasis Android untuk siswa SMA kelas X.

\section{METODE}

Jenis penelitian ini yakni penelitian pengembangan atau dapat disebut juga dengan Research and Development (R\&D). Hasil penelitian yang dihasilkan dari penelitian adalah E-Modul berbasis Android dengan materi trigonometri untuk siswa kelas X SMA. Model pengembangan pada penelitian ini menggunakan model ADDIE. Model ADDIE memiliki kepanjangan Analyze, Design, Develop, Implement and Evaluate (Branch, 2009).

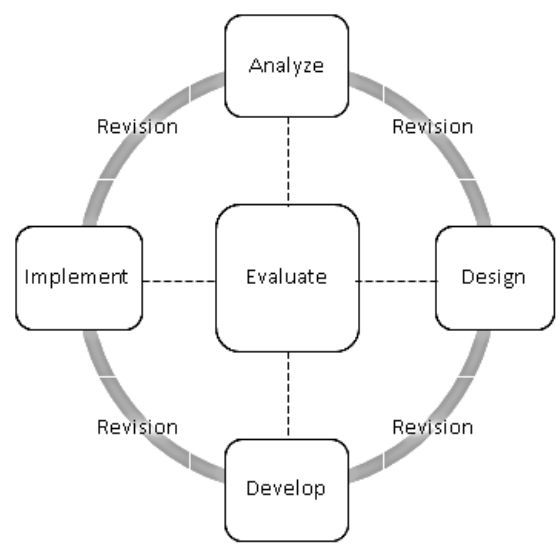

\section{Gambar 1. Diagram Model ADDIE Menurut Branch}

Menurut Riyana (2007), tahapan model ADDIE dimulai dengan tahap analyse. Tahap analisis dilakukan dengan mencari tahu apa yang sudah dipelajari siswa. Identifikasi melakukan beberapa proses, yaitu menganalisis kebutuhan siswa, menganalisis masalah, menganalisis tugas, dan menganalisis kemampuan siswa. Tahap selanjutnya setelah melakukan analisis, dilakukan tahap mendesain. Tahap ini meliputi perumusan tujuan pembelajaran, materi dan tes yang disesuaikan dengan tujuan pembelajaran. Strategi pembelajaran juga di tentukan dan disesuaikan dengan tujuan. Menentukan media, memikirkan sumber belajar juga harus dipertimbangkan. Tahap ketiga adalah tahap develop yang mana media dikembangkan. Material yang dibutuhkan untuk pengembangan juga disiapkan. Setelah itu dilakukan uji coba terlebih dahulu sebelum diimplementasikan yang mana digunakan untuk memperbaiki media yang dikembangkan. Pada tahap implement, semua bahan yang diperlukan untuk implementasi sudah siap digunakan. Bahan yang dikembangkan sesuai dengan fungsinya supaya bahan ajar tersebut dapat digunakan siswa. Tahap yang terakhir adalah penilaian terhadap media yang dikembangkan yang gunanya dapat sebagai perbaikan media tersebut. Media yang telah digunakan dinilai keefektifannya, apakah sudah berhasil sesuai harapan atau belum.

Penelitian E-Modul trigonometri (EMOTIGON) berbasis Android diujicobakan pada 15 siswa kelas XI SMA/SMK yang sudah pernah belajar trigonometri secara online atau daring melalui Google Meet. Penggunaan lembar validasi media, lembar validasi tampilan, lembar kepraktisan media, hasil 
pretest dan posttest dan lembar pendapat siswa serta dokumentasi akan dikumpulkan dan diperoleh data untuk penelitian.

\section{HASIL DAN DISKUSI}

\section{Tahap Analyze (Analisis)}

Tahap yang dilakukan di awal model ADDIE merupakan tahap analisis. Pada tahap ini peneliti memperoleh informasi media pembelajaran berbasis teknologi seperti aplikasi android, website, elearning dan lain-lain. Peneliti juga memperoleh informasi materi matematika kelas X yang dirasa sulit untuk dipahami siswa seperti trigonometri. Dari data yang diperoleh, peneliti tertarik untuk membuat media pembelajaran E-Modul berbasis Android untuk materi trigonometri subbab perbandingan trigonometri sudut berelasi.

E-Modul trigonometri dapat digunakan dengan praktis karena dapat digunakan secara fleksibel hanya dengan memanfaatkan penggunaan smartphone. Media pembelajaran ini tidak membutuhkan koneksi internet (offline) sehingga siswa tidak perlu khawatir kehabisan kuota internet saat menggunakannya.

\section{Tahap Design (Desain)}

Tahap berikutnya yaitu tahap desain. Pada tahap kedua ini, ditemukannya solusi dari analisis yang sudah dilakukan sebelumnya. Berdasarkan analisis, materi yang digunakan untuk media pembelajaran E-Modul berbasis Android yaitu materi trigonometri dengan subbab perbandingan trigonometri sudut berelasi.

Materi tersebut berisi sudut-sudut istimewa, kuadran I sampai dengan IV serta penerapan dalam kehidupan nyata. Materi yang digunakan disesuaikan dengan materi pada kurikulum 2013 yang diterapkan oleh sekolah. Selain itu, media dilengkapi dengan soal dan pembahasan soal. Soal-soal dibagi menjadi 2 bagian, yaitu soal sebagai contoh dari materi yang bahas dan soal-soal untuk latihan. Pada materi, diberikan satu contoh soal pada setiap poin materi dilengkapi dengan pembahasan soal tersebut. Sedangkan soal latihan tidak diberi pembahasan soal.

Aplikasi yang dibuat, dilengkapi dengan tombol-tombol yang dapat ditekan untuk berpindah ke halaman yang lainnya. Diberikan animasi kuadran I, II, III dan IV pada bagian diagram kartesius dengan menggunakan tranformasi geometri seperti rotasi dan pencerminan supaya siswa lebih memahami materi yang diberikan.

\section{Tahap Develop (Pengembangan)}

Media yang sudah didesain, dilanjutkan dengan membuat media tersebut supaya dapat digunakan oleh siswa Sekolah Menengah Atas (SMA). Pengembangan media berupa aplikasi yang dibuat dengan menggunakan aplikasi Android Studio. Tampilan media E-Modul didesain dengan menggunakan Corel Draw dan Adobe After Effect terlebih dahulu sehingga mempermudah dalam pembuatan aplikasi di Android Studio. Tampilan tersebut berupa background, logo, tombol, animasi, dan tulisan. Peneliti membuat rancangan media materi trigonometri subbab perbandingan trigonometri 
sudut berelasi dan soal serta pembahasan soal yang memungkinkan untuk dimasukkan dalam aplikasi E-Modul.

Pengembangan media pada halaman pertama yang akan pertama kali dilihat saat membuka media pembelajaran. Pada halaman ini akan ditampilkan background dan logo E-Modul selama beberapa detik saja dan akan langsung menuju halaman kedua.

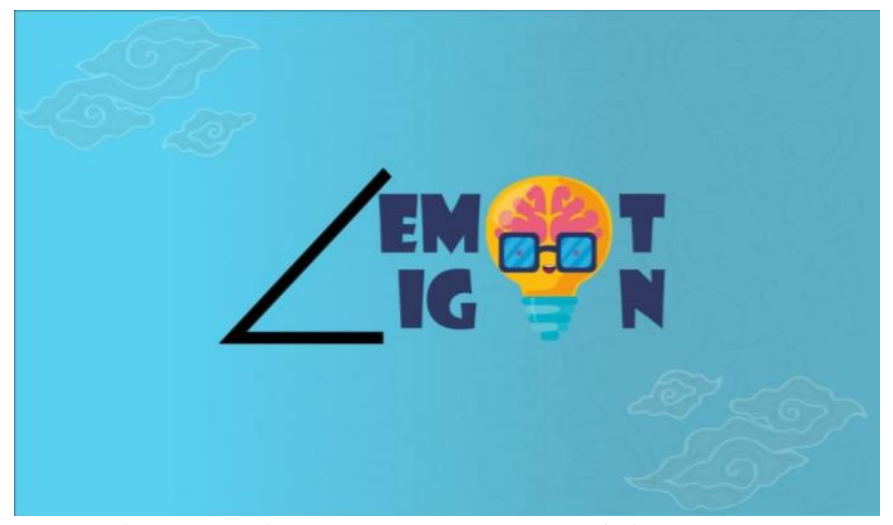

Gambar 2. Halaman Pertama E-Modul Trigonometri

Pada halaman yang pertama tersebut juga mulai diiringi dengan musik, supaya media tidak membosankan dan lebih menarik. Musik yang digunakan akan membuat nyaman siswa dalam belajar trigonometri sampai akhir penggunaan media. Background dari media juga diberi sentuhan corak batik untuk memperindah tampilan dari media. Setelah halaman pertama berakhir, halaman akan langsung berpindah ke halaman kedua. Pada halaman kedua, ada tiga menu atau tombol yaitu start, profil, dan tombol keluar. Ditampilkan juga informasi materi trigonometri subbab perbandingan trigonometri sudut berelasi dan program studi yang diampu peneliti.

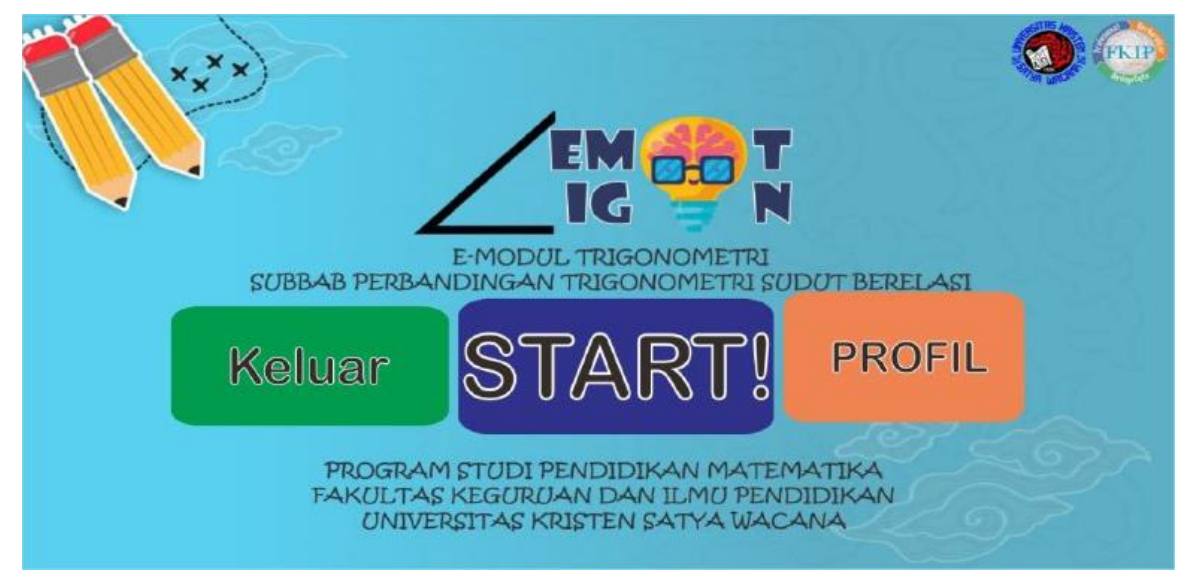

Gambar 3. Halaman Kedua E-Modul Trigonometri

Pada halaman ketiga, terdapat dua tampilan. Tampilan pertama yaitu halaman profil yang berisi profil peneliti dan tujuan dibuatnya media pembelajaran E-Modul Trigonometri. 
Tampilan kedua, berisi menu atau tombol yang berhubungan dengan pembelajaran seperti kompetensi, materi, dan soal latihan yang merupakan tampilan home. Pada halaman ini, diberikan ikon berupa lampu yang berfungsi ketika ditekan akan kembali ke halaman kedua. Kemudian ada juga tombol untuk menuju halaman kompetensi, halaman materi dan halaman latihan soal. Adapun tampilan tersebut seperti berikut.

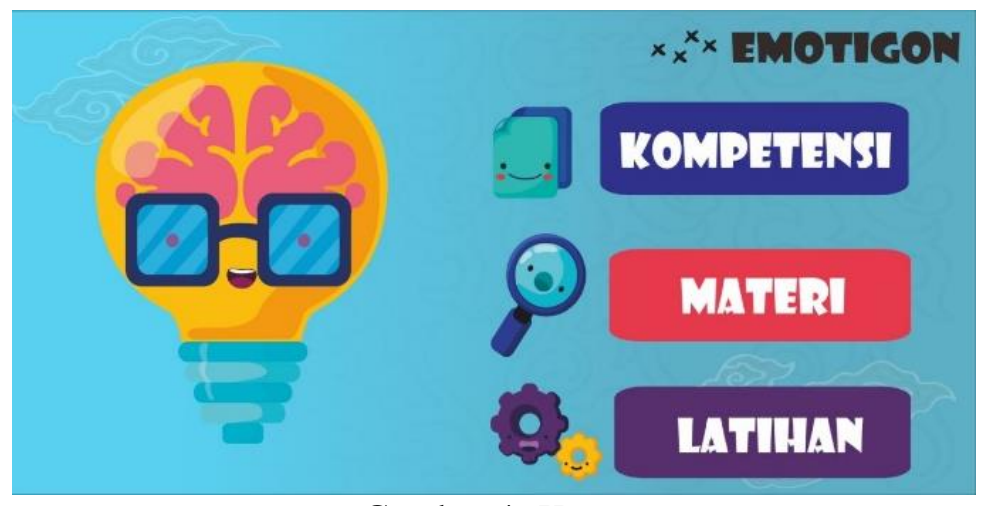

Gambar 4. Home

Pada halaman kompetensi, terdiri dari tiga tampilan. Ketiga tampilan tersebut yaitu kompetensi dasar (KD), indikator pencapaian kompetensi (IPK), dan peta konsep seperi tampak Gambar 5, 6 dan 7.

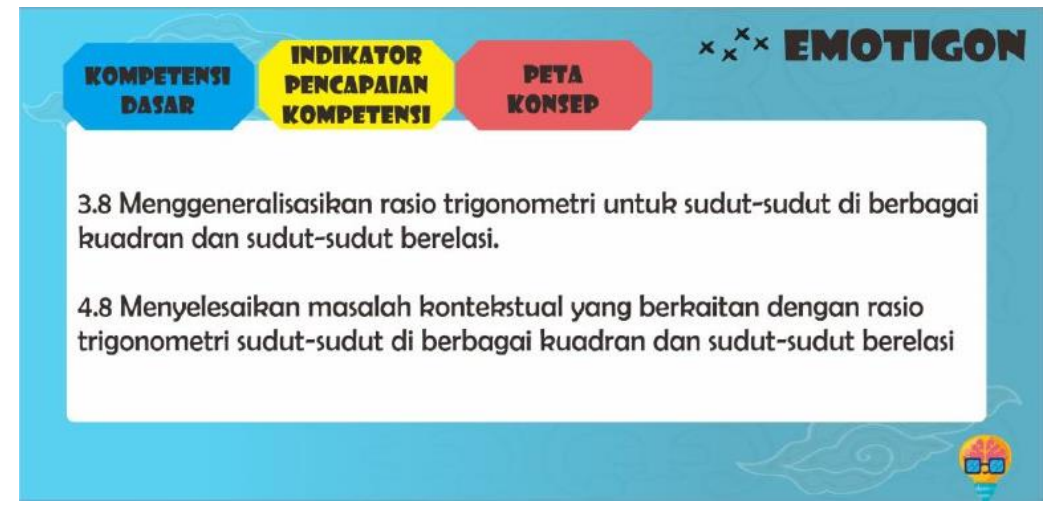

Gambar 5. Kompetensi Dasar

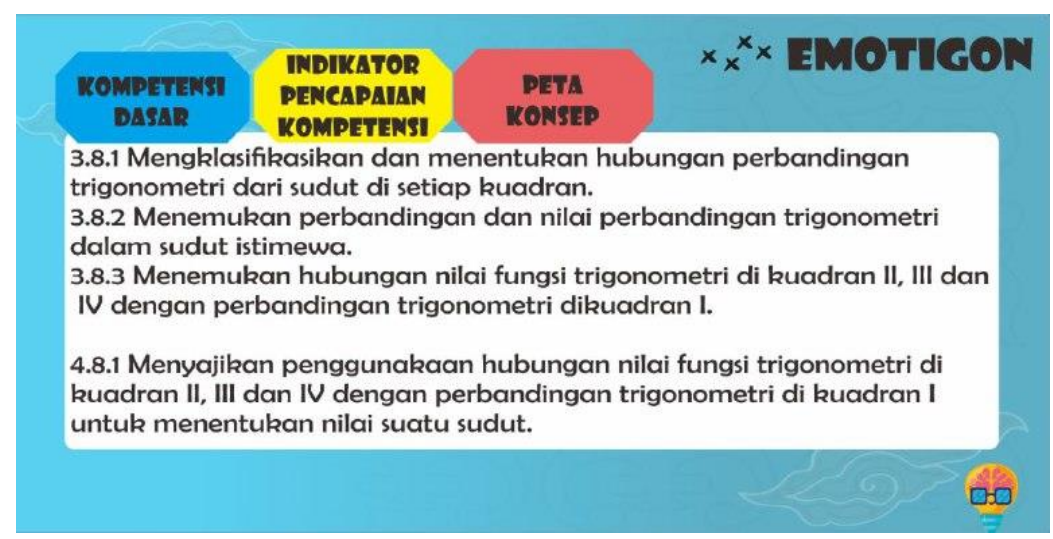

Gambar 6. Indikator Pencapaian Kompetensi 


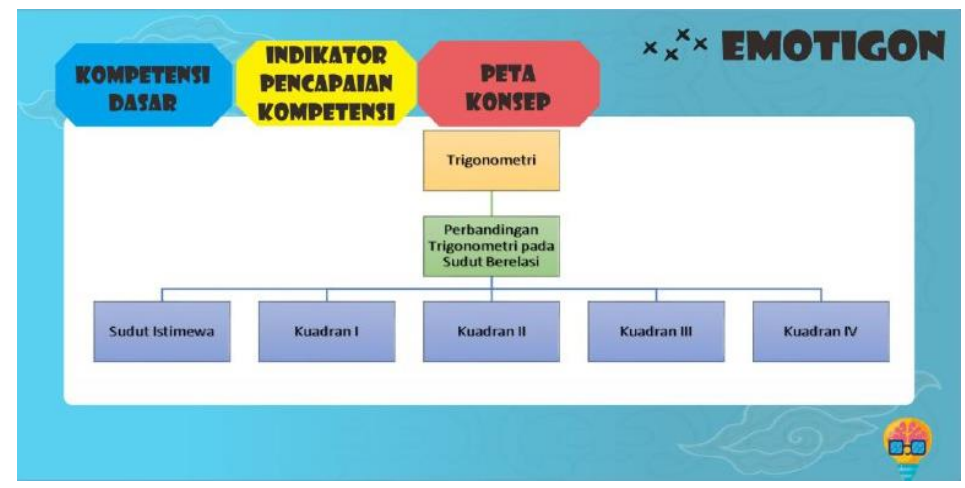

Gambar 7. Peta Konsep

Tampilan kompetensi dasar di ambil dari lampiran 16 kompetensi inti dan kompetensi dasar matematika SMA/MA/SMK/MAK pada materi trigonometri. Berdasarkan kompetensi dasar tersebut, disusun indikator pencapaian kompetensi untuk media pembelajaran E-Modul trigonometri dengan subbab perbandingan trigonometri sudut berelasi. Poin-poin materi yang akan dibahas pada subbab tersebut ditampilkan dengan menggunakan peta konsep.

Tampilan pada materi, akan ada tombol yang dapat ditekan sesuai keinginan pengguna, bisa dimulai dengan konsep kuadran, kuadran I atau menu yang lainnya tetapi ketika sudah memilih satu menu misalnya kuadran I, pengguna tidak dapat kembali ke menu materi melainkan harus menyelesaikan materi dari kuadran I sampai dengan materi selesai.

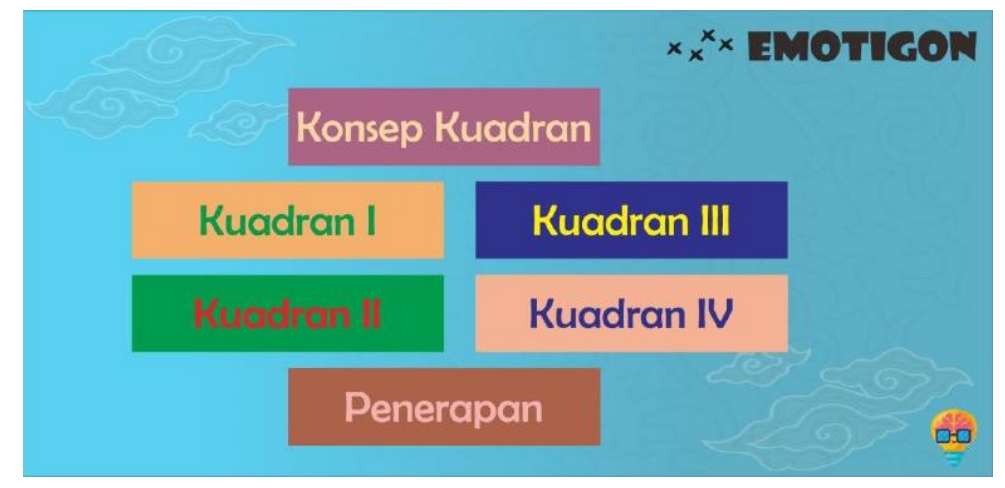

Gambar 8. Menu Materi

Setelah memilih menu materi yang akan dipelajari, materi dimulai dengan animasi pada diagram kartesius. Animasi tersebut berupa rotasi atau pencerminan bangun segitiga siku-siku. Animasi yang ditampilkan juga keterangan besar sudut pada setiap kuadran, dan proses yang terjadi pada setiap kuadrannya. Kemudian, akan ditampilkan hasil dari animasi kuadran tersebut rasio trigonometri. 


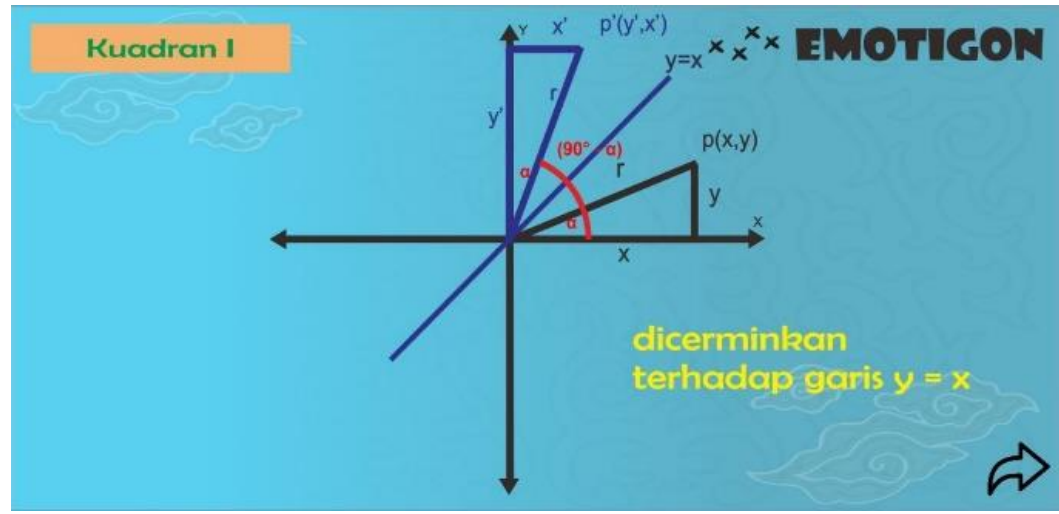

Gambar 9. Animasi Materi

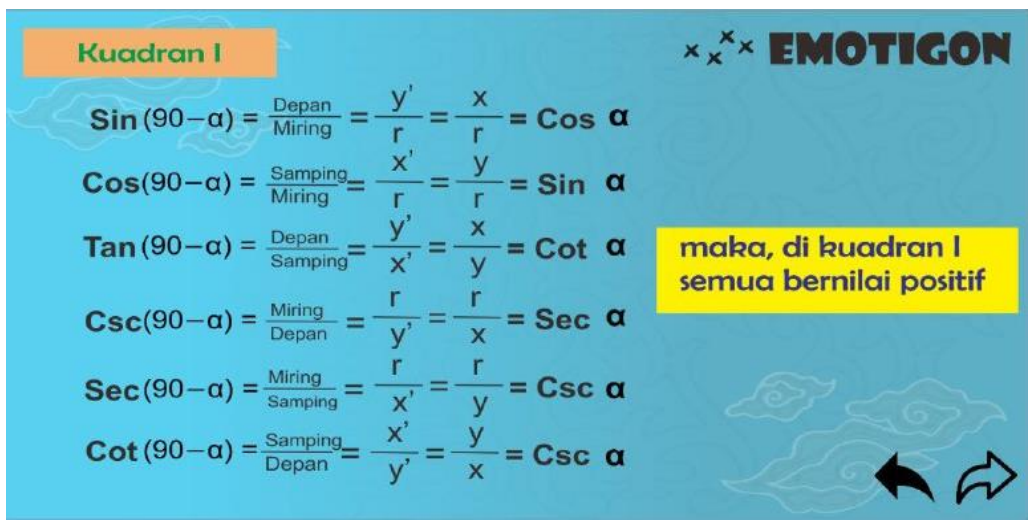

Gambar 10. Rasio Trigonometri

Soal tersebut berhubungan dengan materi yang dibahas sebelumnya. Misal materi kudran I sudah selesai, akan dilanjutkan dengan contoh soal yang berhubungan dengan kuadran I. contoh soal tersebut berupa pilihan ganda yang dilengkapi dengan pembahasan soal seperti pada Gambar 11.

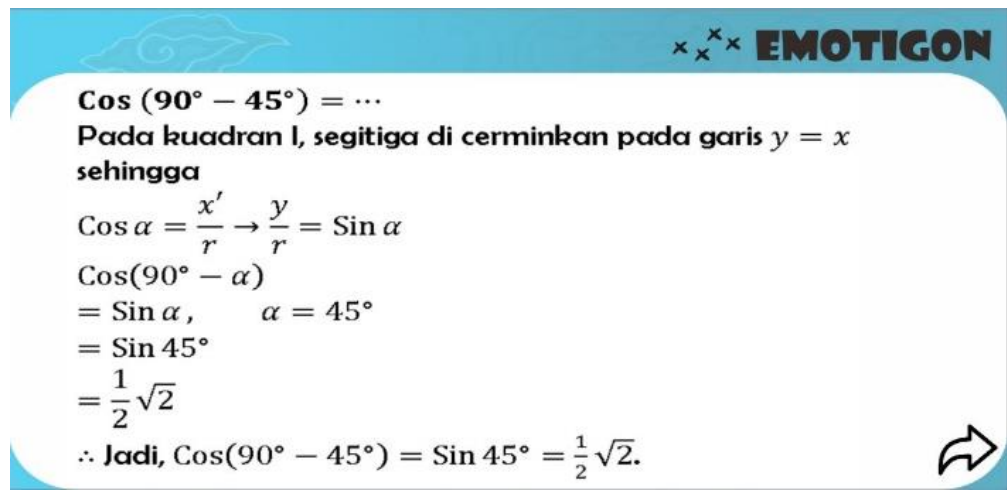

Gambar 11. Contoh Soal dan Pembahasan

Setelah menyelesaikan contoh soal, dapat memulai materi selanjutnya. Setiap kuadran memiliki prinsip yang sama dengan kuadran I. Ketika semua materi selesai, siswa dapat kembali ke halaman home yang ada menu kompetensi, materi dan latihan. Siswa dapat mengulang kembali materi yang dirasa belum paham atau dapat mengerjakan soal latihan.

Pada tampilan latihan, terdapat 10 soal yang dapat digunakan siswa untuk berlatih materi trigonometri subbab perbandingan trigonometri sudut berelasi yang sudah dibahas pada tampilan 
Pengembangan E-Modul Trigonometri (EMOTIGON) Berbasis Android untuk Siswa SMA Kelas X, Avhiyana Ariestazya Sari, Novisita Ratu

materi. Soal-soal tersebut berupa soal pilihan ganda, tetapi tidak ada pembahasan soal melainkan keterangan benar atau salah saat menjawab soal.

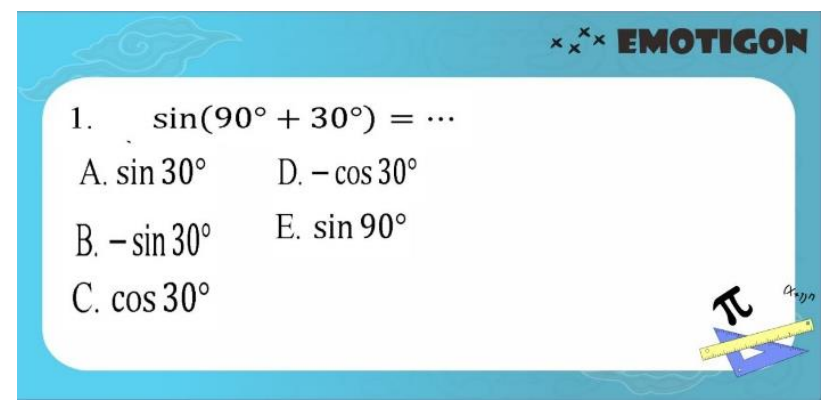

Gambar 12. Latihan

Pada gambar diatas merupakan tampilan untuk latihan. Saat pengguna menjawab soal dengan benar, akan muncul pop up yang menyatakan bahwa jawaban benar dan di beri pilihan lanjut soal atau kembali ke home. Sedangkan jika jawaban salah, maka akan muncul pop up yang menyatakan jawaban salah dan pengguna diminta untuk kembali ke materi. Tampilan tersebut seperti gambar berikut.

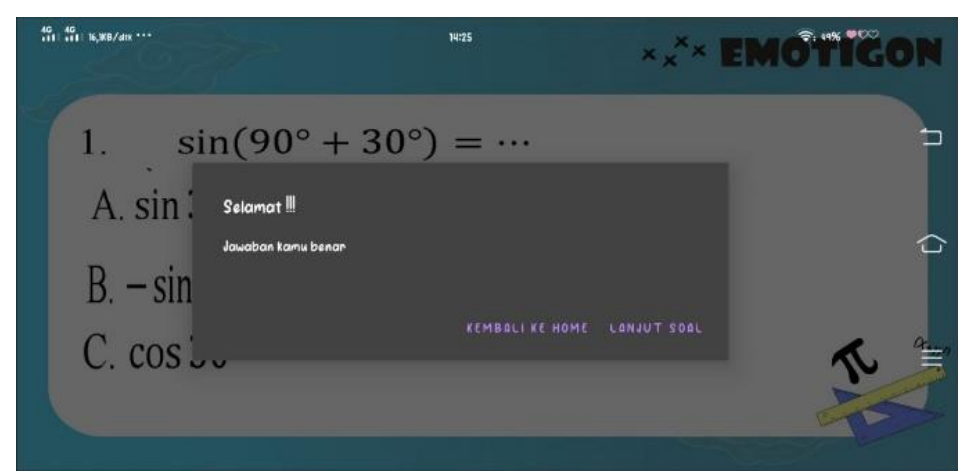

Gambar 13. Pop Up Jawaban Benar Latihan

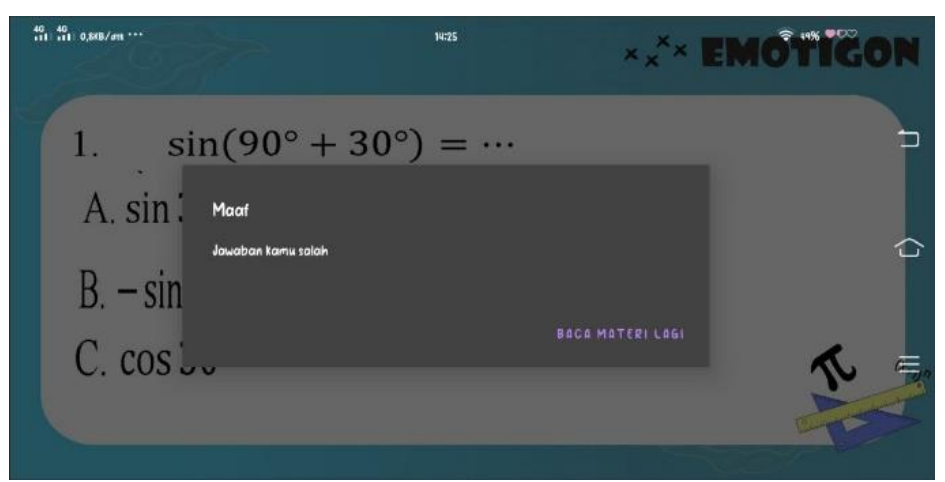

Gambar 14. Pop Up Jawaban Salah Latihan

Pengembangan aplikasi selanjutnya dilakukan validasi oleh ahli materi dan ahli media serta guru matematika SMA/SMK. Proses ini dilakukan agar media mendapatkan kritik dan saran yang akan digunakan untuk memperbaiki media sebelum diimplementasikan ke siswa. Diperoleh rata-rata 4,2 presentase $84 \%$ masuk dalam kategori valid pada validasi materi. Validasi tampilan diperoleh 
rata-rata sebesar 4,4 dengan presentase $88 \%$ yang dikategorikan valid. Penilaian kepraktisan media juga dinilai dengan rata-rata yang diperoleh 4,5 sehingga presentase 90\% dalam kategori praktis.

Ahli media dan ahli materi menyatakan sudah layak dengan revisi. Media direvisi sesuai saran dan kritikan dari para ahli. Media yang direvisi dengan menambahkan penerapan subbab perbandingan sudut berelasi pada kehidupan nyata yang sebelumnya belum dicantumkan pada aplikasi E-Modul. Setelah direvisi, tampilan media tampak seperti Gambar 15 dan 16.

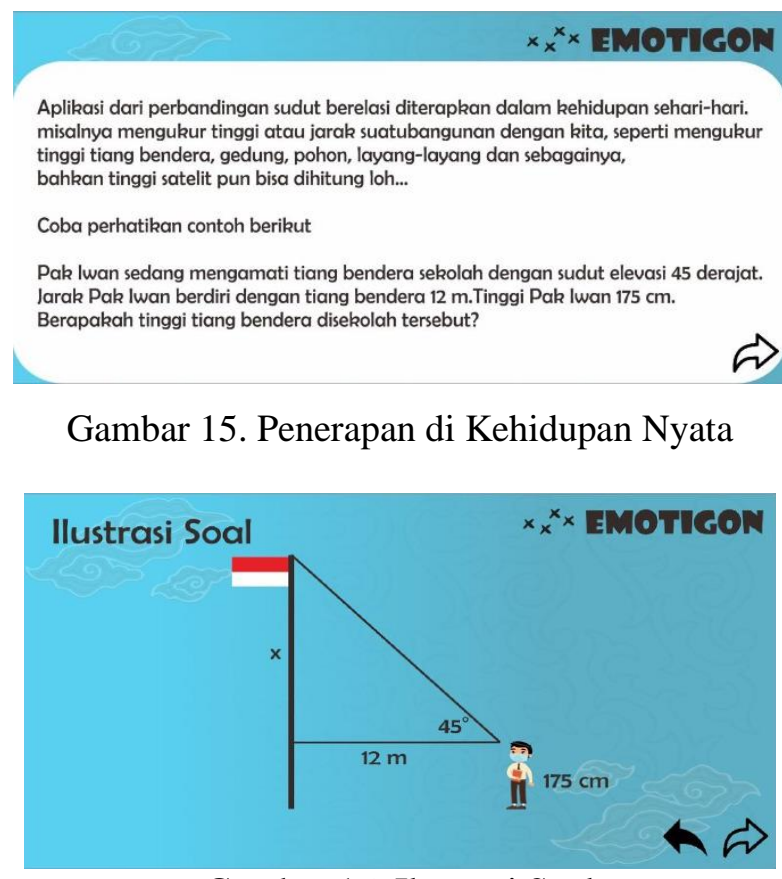

Gambar 16. Ilustrasi Soal

Penelitian pengembangan media E-Modul trigonometri berbasis Android telah disetujui melalui validasi dari validator. Hasil validasi dari aspek materi dan aspek tampilan didapat dengan presentase sebesar $86 \%$, sehingga dikatakan bahwa media E-Modul trigonometri berbasis Android valid. Media yang dikembangkan memiliki kelebihan dalam tampilan yang menarik dengan berbagai warna, corak dan tombol-tombol, media juga fleksibel, namun media ini juga memiliki kekurangan seperti dapat terjadi bug, soal yang diberikan masih sedikit dan media hanya dapat digunakan untuk Android saja.

\section{Tahap Implement (Implementasi)}

Pada tahap keempat, yaitu tahap implementasi. Tahap ini diselenggarakannya pembelajaran atau penyampaian materi trigonometri kepada siswa dengan menggunakan E-Modul trigonometri berbasis Android yang telah dibuat dan telah melalui validasi. Implementasi dilakukan kepada siswa kelas XI yang sudah pernah mempelajari trigonometri berjumlah 15 orang yang terdiri dari 11 siswa SMA Negeri 2 Salatiga, 3 siswa SMA Negeri 3 dan 1 siswa SMK Negeri 2 di Salatiga. Pada tahap ini, siswa melakukan pretest, uji coba media, posttest dan diakhiri dengan mengisi lembar pendapat.

Siswa diberikan soal pretest sebelum menggunakan E-Modul trigonometri berbasis Android pada tanggal 1 September 2021. Uji coba dilakukan pada hari berikutnya pada tanggal 2 September 2021. Selama uji coba, siswa berperan aktif dalam menggunakan media E-Modul trigonometri 
berbasis Android. Tujuan dilakukan uji coba media ini yaitu untuk mengetahui E-Modul trigonometri berbasis Android berdampak positif terhadap siswa saat belajar trigonometri atau tidak. Setelah melakukan uji coba, pada tanggal 3 September 2021 diberikan soal posttest untuk mengetahui adakah pengaruh dari E-Modul trigonometri berbasis Android ketika digunakan siswa dalam memahami dan mengerjakan soal pada materi trigonometri. Selain tes, siswa juga diberikan angket berupa google form untuk mengetahui respon siswa saat menggunakan E-Modul trigonometri berbasis Android. Pemberian angket kepada siswa, setelah dilakukannya posttest.

\section{Tahap Evaluate (Evaluasi)}

Tahap paling akhir pada model ADDIE yakni tahap evaluasi. Pada tahap ini dilakukan proses menilai berhasil atau tidaknya pembelajaran dengan menggunakan E-Modul trigonometri berbasis Android. Pada tahap ini dengan melakukan perbandingan hasil belajar pretest siswa dengan hasil belajar posttest siswa.

Sebelum uji coba penggunaan E-Modul trigonometri berbasis Android, diambil nilai siswa melalui pretest, dilanjutkan menggunakan aplikasi E-Modul trigonometri berbasis Android yang sudah di download pada smartphone siswa, dan diakhiri dengan posttest serta pengisian lembar pendapat atau respon siswa. Berdasarkan pretest dan posttest yang sudah dilakukan, didapat hasil tes dari 15 siswa. Data akan dianalisis dan diolah untuk mengetahui apakah E-Modul trigonometri berbasis Android efektif. Uji awal yang dilakukan yaitu dengan melakukan uji normalitas. Hasil uji normalitas seperti tampak pada Tabel 1.

Tabel 1. Uji Normalitas

One-Sample Kolmogorov-Smirnov Test

\begin{tabular}{|l|l|r|}
\hline \multicolumn{2}{|l|}{} & Unstandardized Residual \\
\hline $\mathrm{N}$ & Mean & 15 \\
\hline \multirow{2}{*}{ Normal Parameters } & Stb & .0000000 \\
\cline { 2 - 3 } & Std. Deviation & 12.93474748 \\
\hline \multirow{2}{*}{ Most Extreme Differences } & Absolute & .109 \\
\cline { 2 - 3 } & Positive & .093 \\
\cline { 2 - 3 } & Negative & -.109 \\
\hline \multicolumn{2}{|l|}{ Test Statistic } & .109 \\
\hline Asymp, Sig. (2-tailed) & $.200^{\mathrm{c}, \mathrm{d}}$ \\
\hline
\end{tabular}

Menurut Tabel Normalitas diatas, uji normalitas menggunakan uji Kolmogorov-Smirnov dengan subjek penelitian sebanyak 15 siswa. Hasil uji normalitas tersebut memperlihatkan nilai signifikan 0,200 > 0,05. Sehingga didapat kesimpulan data tersebut mempunyai distribusi normal. Setelah dilakukan uji normalitas, pengujian dilanjutkan dengan menggunakan uji paired sample t-test seperti tabel dibawah ini. 
Tabel 2. Uji Paired Sample T-Test

Paired Samples Test

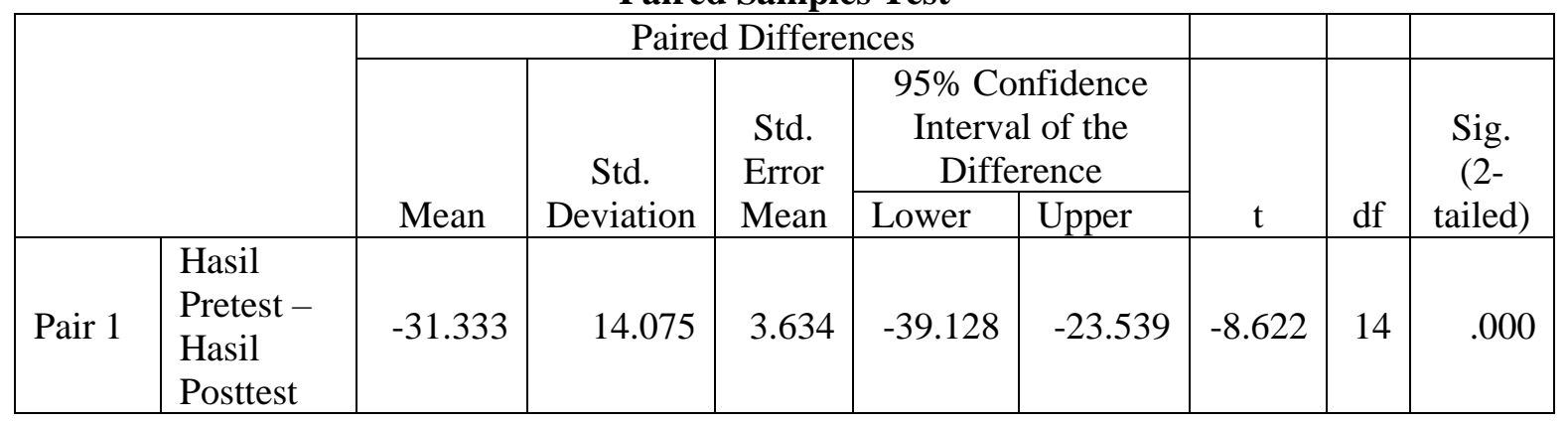

Hasil uji paired sample t-test tersebut menunjukkan sig. (2-tailed) dari hasil pretest dan hasil posttest sebesar 0,000 kurang dari 0,05. Sehingga diperoleh kesimpulan bahwa terdapat perbedaan dari rata-rata hasil pretest dengan rata-rata hasil posttest yang berarti penggunaan E-Modul trigonometri berbasis Android efektif digunakan sebagai sarana pembelajaran trigonometri.

Berdasarkan lembar pendapat yang telah diisi oleh siswa menunjukkan bahwa media E-Modul trigonometri berbasis Android memiliki tampilan yang menarik dengan iringan musik agar tidak terasa bosan, mempermudah siswa dalam memahami materi trigonometri, dapat digunakan dengan praktis dan fleksibel, serta menarik minat siswa dalam belajar. Hasil uji coba terbatas menunjukkan bahwa penggunaan E-Modul trigonometri berbasis Android terhadap pemahaman serta hasil belajar siswa dapat ditingkatkan. Kemudian dari respon positif siswa saat menggunakan media seperti memberikan saran untuk dapat digunakan pada materi lain.

\section{KESIMPULAN}

Berdasarkan uraian hasil penelitian serta pembahasan, sehingga diperoleh beberapa kesimpulan. Pertama, media E-Modul trigonometri (EMOTIGON) berbasis Android untuk siswa kelas X, dikembangakan dengan model pengembangan yang digunakan yakni model ADDIE yang mempunyai 5 tahap yaitu analyze, design, develop, implement and evaluate. Kedua, media E-Modul trigonometri (EMOTIGON) berbasis Android untuk siswa kelas X dapat digunakan sebagai sarana belajar mandiri dan sarana mengerjakan soal bagi siswa kelas X karena sudah dinyatakan Valid, berdasarkan hasil validasi oleh validator. Media E-Modul trigonometri berbasis Android pada materi trigonometri juga dinyatakan Efektif berdasarkan hasil dari nilai pretest siswa rata-rata 34,67 dan posttest rata-ratanya sebesar 66. Ketiga, media E-Modul trigonometri (EMOTIGON) berbasis Android untuk siswa kelas X dinyatakan Praktis berdasarkan validator kepraktisan. Kepraktisan media juga ditentukan dari pendapat siswa pada lembar pendapat siswa setelah menggunakan media. Siswa yang sudah menggunakan media, memberikan pendapat bahwa media membuat siswa tertarik dan mempermudah siswa dalam belajar matematika khususnya materi trigonometri secara fleksibel tidak tergantung tempat dan waktu. Penyajian materi pada EMOTIGON juga membuat siswa terbantu pada 
Pengembangan E-Modul Trigonometri (EMOTIGON) Berbasis Android untuk Siswa SMA Kelas X, Avhiyana Ariestazya Sari, Novisita Ratu

pemahaman materi trigonometri. Banyak siswa menyarankan supaya media dapat dikembangkan untuk materi lainnya dan dapat dioperasikan pada IOS.

\section{UCAPAN TERIMA KASIH}

Peneliti mengucapkan terimakasih kepada Tuhan Yang Maha Esa yang menyertai, memberkati serta melindungi peneliti dalam penyusunan penelitian, kepada keluarga yang selalu mendukung dan banyak mendoakan, kepada Ibu dosen pembimbing yang telah membimbing dari awal penyusunan dengan saran atau masukan yang membangun sampai akhir. Tak lupa juga kepada validator yang telah menguji dan menilai dengan masukan dan saran, kepada siswa kelas XI SMA/SMK yang sudah membantu dalam penelitian, serta untuk teman-teman yang selalu memberi dukungan dan menyemangati serta mendoakan selama berlangsungnya penelitian.

\section{REFERENSI}

Abdullah, F. S., \& Yunianta, T. N. H. (2018). Pengembangan Media Pembelajaran Matematika Trigo Fun Berbasis Game Edukasi Menggunakan Adobe Animate Pada Materi Trigonometri. AKSIOMA: Jurnal Program Studi Pendidikan Matematika, 7(3), 434. https://doi.org/10.24127/ajpm.v7i3.1586

Arisudawan, K., Santyadiputra, G. S., \& Sindu, I. G. P. (2017). Pengembangan E-Modul Mata Pelajaran Rancang Bangun Jaringan Berbasis Project Based Learning Kelas Xi Di Smk Negeri 3 Singaraja. Kumpulan Artikel Mahasiswa Pendidikan Teknik Informatika (KARMAPATI), 6(3), 374. https://doi.org/10.23887/karmapati.v6i3.12074

Branch, Robert. (2009). Instructional design the ADDIE approach.USA: Springer

Ekawati, A. (2016). Penggunaan Software Geogebra Dan Microsoft Mathematic Dalam Pembelaran Matematika. Math Didactic, 2(3), 148-153. https://doi.org/10.33654/math.v2i3.43

Herawati, N. S., \& Muhtadi, A. (2018). Pengembangan modul elektronik (e-modul) interaktif pada mata pelajaran Kimia kelas XI SMA. Jurnal Inovasi Teknologi Pendidikan, 5(2), 180-191. https://doi.org/10.21831/jitp.v5i2.15424

Majid, E. (2020). Pengembangan e-modul android berbasis metakognisi sebagai media pembelajaran biologi peserta didik kelas xii di tingkat sma/ma. Jurnal Pendidikan Sains, 1(8), 2. http://repository.radenintan.ac.id/11216/1/.pdf

Permatasari, E. A., Mudakir, I., \& Fikri, K. (2017). Pengembangan E-modul Berbasis Adobe Flash Pada Pokok Bahasan Sistem Reproduksi Untuk Kelas IX MIPA SMA. Saintifika, 19(1), 57-65.

Putri, A. S. (2019). Pengembangan E-Modul Pembelajaran Penyelesaian Tepi Pakaian Pada Mata Pelajaran_Dasar Teknologi_Menjahit. Eprints@UNY, 1-160. http://eprints.uny.ac.id/id/eprint/65825

Putu, N., Widiantari, E., \& Ariyani, A. (2019). Meningkatkan Pemahaman Konsep Trigonometri Siswa Kelas XI MIPA 4 SMAN 11 Semarang Melalui Strategi PQ4R Berbantu Kartu Soal. 2, 
$72-78$.

Rachmayani, D. W. I. (2014). PENERAPAN PEMBELAJARAN RECIPROCAL TEACHING UNTUK MENINGKATKAN KEMAMPUAN KOMUNIKASI MATEMATIS DAN KEMANDIRIAN BELAJAR MATEMATIKA SISWA. Jurnal Pendidikan Unsika, 2(November), 13-23.

Rifa'i, M., \& Nisa, R. (2019). PENGEMBANGAN E-MODUL KALKULUS BERBASIS GEOGEBRA DENGAN DUKUNGAN WEBSITE MOODLE. Math Didactic, 5(3), 259-268.

Riyana, C. (2007). Implementasi Pembelajaran Teknologi Informasi Dan Komunikasi (Tik) Di Sekolah. Majalah Ilmiah Pembelajaran, 3(2).

Sadikin, A., \& Hakim, N. (2019). Interactive Media Development of E-Learning in Welcoming 4 . 0 Industrial Revolution On Ecosystem Material for High School Students Pengembangan Media E-Learning Interaktif Dalam Menyongsong Revolusi Industri 4 . Jurnal Ilmiah Pendidikan Biologi, 5(2), 131-138.

Sarwiko, D. (2012). Pengembangan media pembelajaran berbasis multimedia interaktif menggunakan macromedia director mx (Studi kasus mata kuliah Pengolahan Citra pada jurusan S1 sistem informasi). Multimedia.

Setyono, T., Eka, L., \& Deswita, H. (2017). Pengembangan Media Pembelajaran Matematika Dengan Menggunakan Macromedia Flash Pada Materi Bangun Ruang Kelas VIII Sekolah Menengah Pertama. Jurnal Fakultas Keguruan Dan Ilmu Pendidikan Universitas Pasir Pengaraian, 2(1), $1-10$.

Suarsana, I. M., \& Mahayukti, G. A. (2013). PENGEMBANGAN E-MODUL BERORIENTASI PEMECAHAN MASALAH UNTUK MENINGKATKAN KETERAAMPILAN BERPIKIR KRITIS MAHASISWA. Jurnal Pendidikan Indonesia, 2(2), 264-275.

Ula, I. R., \& Fadila, A. (2018). Pengembangan E-Modul Berbasis Learning Content Development System Pokok Bahasan Pola Bilangan SMP. Desimal: Jurnal Matematika, 1(2), 201. https://doi.org/10.24042/djm.v1i2.2563. 